\title{
PENGARUH KARAKTERISTIK PEKERJAAN DAN KOMPETENSI TERHADAP KINERJA MELALUI KOMITMEN ORGANISASIONAL
}

\author{
Bambang Heri Purwanto dan Euis Soliha \\ Fakultas Ekonomika dan Bisnis Universitas Stikubank Semarang \\ e-mail:b_heripurwanto@yahoo.com dan soliha.euis@gmail.com
}

\begin{abstract}
The purpose of this study was to determine and analyze the relationship between job characteristics, competencies and organizational commitment to employee performance Pekalongan District Health Office. The population for this study is Pekalongan District Health Bureau staff totaling 104 people. Samples were taken by using census method. The research instrument was a questionnaire. The collected data was then processed using the technique of multiple regression analysis with SPSS (Statistical Package for Social Science). The analysis showed 1) the characteristics of the job does not affect the organizational commitment, 2) competence and significant positive effect on organizational commitment, 3) job characteristics and significant positive effect on performance, 4) the competence of positive and significant impact on performance, 5) organizational commitment is not berpengaruhi the performance.
\end{abstract}

Keywords: job characteristics, competencies, organizational commitment, performance

\begin{abstract}
Abstrak: Tujuan penelitian ini adalah untuk mengetahui dan menganalisis ada tidaknya hubungan antara karakteristik pekerjaan, kompetensi dan komitmen organisasional terhadap kinerja pegawai Dinas Kesehatan Kabupaten Pekalongan. Populasi yang diambil untuk penelitian ini adalah pegawai Dinas Kesehatan Kabupaten Pekalongan yang berjumlah 104 orang. Sampel diambil dengan menggunakan metode sensus. Instrumen penelitian adalah kuesioner. Data yang terkumpul selanjutnya diolah menggunakan teknik analisis regresi berganda dengan bantuan perangkat lunak SPSS (Statistical Package for Social Science). Hasil analisis menunjukkan 1) karakteristik pekerjaan tidak berpengaruh terhadap komitmen organisasional, 2) kompetensi berpengaruh positif dan signifikan terhadap komitmen organisasional, 3) karakteristik pekerjaan berpengaruh positif dan signifikan terhadap kinerja, 4) kompetensi berpengaruh positif dan signifikan terhadap kinerja, 5) komitmen organisasional tidak berpengaruhi terhadap kinerja.
\end{abstract}

Kata kunci: karakteristik pekerjaan, kompetensi, komitmen organisasional, kinerja

\section{PENDAHULUAN}

Potret aparat pemerintah di Indonesia sering berkisar pada rendahnya profesionalisme, tingkat kesejahteraan yang belum memadai, distribusi dan komposisi pegawai yang belum ideal, penempatan dalam jabatan yang belum didasarkan pada kompetensi, penilaian kinerja yang belum objektif, kenaikan pangkat yang belum didasarkan pada prestasi kerja, budaya kerja dan ethos kerja yang masih rendah dan penerapan peraturan disiplin yang tidak dilaksanakan secara konsisten (Effendi, 2006). Beberapa hal tersebut merupakan masalah yang cukup menarik dan penting, karena bermanfaat bagi kepentingan individu, masyarakat, bangsa dan negara. Kinerja aparat 
pemerintah bertujuan untuk memberikan pelayanan publik yang mendahulukan kepentingan umum, mempermudah urusan publik, mempersingkat pelayanan dan memberikan kepuasan kepada publik (Rezsa, 2008).

Ada beberapa faktor yang mempengaruhi turunnya kualitas kinerja pegawai antara lain, beban kerja yang berlebihan, terlalu banyaknya pekerjaan, sedikitnya waktu yang tersedia berdampak pada menurunnya kualitas kerja. Masih ada beberpa pejabat eselon IV yang terlalu banyak melakukan tugas administratif dsb. Besarnya tanggung jawab yang harus dipikul namun tidak disertai wewenang dalam membuat keputusan, adanya campur tangan atasan yang berlebihan sampai ke aspek tehnis.

Terjadinya pengkotak - kotakan penugasan yang berdampak pada meningkatnya isolasi sosial dalam lingkungan kerja, adanya perlakuan yang tidak adil, perlakuan yang tidak sama dan bukan berdasarkan "kompetensi" melainkan "like or dislike". Misal: kebijakan yang arogan, tidak adanya sistem imbalan yang jelas dan baku. Dan terjadinya konflik nilai: Ketidak-sesuaian antara prinsip pribadi dengan tuntutan pekerjaan, yang menghalalkan segala cara namun aktifitas tersebut bertentangan dengan nilai moral yang diyakininya.

Sumber daya manusia dapat memberikan nilai tambah (added value) sebagai tolok ukur keberhasilan bisnis. Kualitas SDM ini sebagai competitive advantage dari unit kerja (Bank, 2008) Sumber daya manusia sebagai tenaga kerja merupakan factor penting dalam proses kinerja suatu organisasi. Hal ini juga berlaku dalam organisasi pada system Pemerintahan. Sumber Daya Manusia yang berkualitas dengan kuantitas yang tepat akan memberikan optimalisasi sumber daya manusia dalam pelaksanaan kinerja.

Dinas Kesehatan Kabupaten Pekalongan memegang peranan penting dalam pembangunan kesehatan di Wilayah Kabupaten pekalongan. Dinas Kesehatan Kabupaten pekalongan merupakan Satuan Kerja Perangkat Daerah (SKPD) dengan kewenangan wajib dalam mencapai Visi dan Misi serta tujuan Pemerintah Kabupaten Pekalongan dalam meningkatkan derajat kesehatan sesuai Standar Pelayanan Minimal. Untuk dapat melaksanakan tanggungjawab tersebut sangatlah diperlukan kinerja yang baik, dibutuhkan pegawai yang profesional sesuai kompetensi dengan karakterstik pekerjaan untuk meningkatkan kinerja sesuai amanah undang-undang. Namun Fenomena yang terjadi selama ini pada Dinas Kesehatan Kabupaten Pekalongan dalam hal penempatan personil kurang memperhatikan kemampuan (competence) dari personil tersebut sehingga tuntutan masyarakat yang menghendaki profesionalisme aparat pemerintah belum terpenuhi sehingga pelayanan kepada masyarakat belum sepenuhnya memuaskan, hanya sebagian pegawainya yang mampu menjalankan tugas sesuai penilaian prestasi kerjanya baik dari segi kualitas maupun kuantitas. Pada dasarnya karyawan pada Dinas Kesehatan Kabupaten Pekalongan yang puas terhadap pekerjaanya akan cenderung memiliki kinerja yang tinggi pula. Kinerja pegawai tidak lepas dari peran pemimpinnya. menurut Bass (1990), peran kepemimpinan atasan dalam memberikan kontribusi pada karyawan untuk pencapaian kinerja yang optimal dilakukan melalui lima cara, yaitu: (1) pemimpin mengklarifikasi apa yang diharapkan dari karyawannya, secara khusus tujuan dan sasaran dari kinerja mereka, (2) pemimpin menjelaskan bagaimana memenuhi harapan tersebut,(3) pemimpin mengemukakan criteria dalam melakukan evaluasi dari kinerja secara efektif, (4) pemimpin memberikan umpan balik ketika karyawan telah mencapai sasaran, dan (5) pemimpin mengalokasikan imbalan berdasarkan hasil yang telah mereka capai.

Berdasarkan pendapat dari beberapa pakar seperti Steer \& Porter Gibson et.al, Leslie and Lyold, bahwa kinerja pegawai dipengaruhi oleh beberapa faktor seperti motivasi, 
kepuasan kerja, komitmen organisasi, kepemimpinan, dan lingkungan kerja. Komitmen organisasi menjadi perhatian penting karena memberikan dampak signifikan terhadap perilaku kerja seperti kinerja, kepuasan kerja, absensi karyawan dan juga turn over karyawan.Komitmen dalam organisasi akan membuat pekerja memberikan yang terbaik kepada organisasi tempat dia bekerja. Van Scooter (2000) menyatakan bahwa pekerja dengan komitmen yang tinggi akan lebih berorientasi pada kerja. Hal ini sangat menarik untuk diteliti pada Dinas Kesehatan Kabupaten Pekalongan, apakah karakteristik pekerjaan dan kompetensi mempengaruhi kinerja pegawai, sehingga diperlukan upaya -upaya dalam meningkatkan kemampuan sumber daya manusia dan kemampuan tersebut diwujudkan dalam bentuk kinerja pegawai. Apakah komitmen organisasi seorang pegawai akan mendorong prestasi kerjanya menjadi lebih baik? Tujuan penelitian ini adalah untuk mengetahui pengaruh Karakteristik dan Kompetensi SDM terhadap kinerja pegawai melalui komitmen organisasional sebagai variabel mediasi pada Pegawai Dinas Kesehatan Kabupaten Pekalongan

\section{KAJIAN PUSTAKA}

Kinerja. Kinerja berasal dari kata job performance atau actual performance (prestasi kerja atau prestasi sesungguhnya yang dicapai seseorang) yaitu hasil kerja secara kualitas dan kuantitas yang dicapai oleh seorang pegawai dalam melaksanakan tugasnya sesuai dengan tanggung jawab yang diberikan kepadanya. (Mangkunegara (2005:67) Menurut Cokroaminoto (2007) pengertian kinerja karyawan menunjuk pada kemampuan karyawan dalam melaksanakan keseluruhan tugas-tugas yang menjadi tanggungjawabnya. Tugas-tugas tersebut biasanya berdasarkan indikator-indikator keberhasilan yang sudah ditetapkan. Sebagai hasilnya akan diketahui bahwa seseorang karyawan masuk dalam tingkatan kinerja tertentu. Kinerja menurut Gibson (1997) adalah hasil dari pekerjaan yang terkait dengan tujuan organisasi seperti kualitas, kuantitas dan effisiensi kerja. Kinerja yaitu perilaku yang ditunjukkan seseorang dalam bekerja, hasil nyata (outcomes) dan penilaian pada faktor seperti mencakup segi usaha, loyalitas, potensi, kepemimpinan dan moral kerja (Wexley dan Yukl: 1998).

Kompetensi. Kompetensi adalah kemampuan kerja setiap individu yang mencakup aspek pengetahuan, keterampilan dan sikap kerja yang sesuai dengan standar yang ditetapkan. Kompetensi adalah sebuah pernyataan terhadap apa yang seseorang harus lakukan ditempat kerja untuk menunjukan pengetahuannya, keterampilannya dan sikap sesuai dengan standar yang dipersyaratkan,

Kompetensi dapat berupa penguasaan masalah, ketrampilan kognitif maupun ketrampilan perilaku, tujuan,perangai, konsep diri, sikap atau nilai. Setiap orang dapat diukur dengan jelas dan dapat ditunjukkan untuk membedakan perilaku unggul atau yang berprestasi rata-rata. Penguasaan masalah dan ketrampilan relatif mudah diajarkan, mengubah sikap dan perilaku relatif lebih sukar. Sedangkan mengubah tujuan dapat dilakukan tetapi prosesnya panjang,lama dan mahal.

Spencer and Spencer (1993:9) mengemukakan bahwa kompetensi individu merupakan karakter sikap dan perilaku, atau kemampuan individual yang relatif bersifat stabil ketika menghadapi suatu situasi di tempat kerja yang terbentuk dari sinergi antara watak, konsep diri, motivasi internal, serta kapasitas pengetahuan kontekstual.

Menurut Spencer and Spencer (1993:34) mengklasifikasikan dimensi dan komponen kompetensi individual menjadi tiga, yaitu: (a). kompetensi intelektual, (b). kompetensi 
emosional, dan (c). kompetensi sosial. Nampaknya spencer and Spencer telah melihat komponen kompetensi dari aspek dimensi manusia dan hubungan antarp-personal, tetapi belum menghasilkan komponen kompetensi spiritual.

Karakteristik Pekerjaan. Ada beberapa pengertian karakteristik pekerjaan. Dalam suatu organisasi keberadaan pekerjaan disusun mulai dari desain pekerjaan, yaitu penetapan kegiatan-kegiatan individu atau kelompok karyawan secara organisasi (Handoko, 2004) Tujuannya adalah untuk mengatur penugasanpenugasan kerja yang memenuhi kebutuhan-kebutuhan organisasi, teknologi dan keperilakuan. Jadi karakteristik pekerjaan adalah uraian pekerjaan yang menjadi pedoman dalam bekerja dan dalam pelaksanaannya bisa mencapai kepuasan.

Menurut Stephen Robbins (1996:208), teori karakteristik pekerjaan adalah upaya mengidentifikasikan karakteristik tugas dari pekerjaan, bagaimana karakteristik itu digabung untuk membentuk pekerjaan yang berbeda dan hubungannya dengan motivasi, kepuasan kerja dan kinerja karyawan. Dalam Simamora, (2004:129) model karakteristik pekerjaan (job characteristic models) merupakan suatu pendekatan terhadap pemerkayaan pekerjaan (job enrichment). Program pemerkayaan pekerjaan berusaha merancang pekerjaan dengan cara membantu para pemangku jabatan memuasakan kebutuhan mereka akan pertumbuhan, pengakuan, dan tanggung jawab. Pemerkayaan pekerjaan menambahkan sumber kepuasan kepada pekerjaan. Metode ini meningkatkan tanggung jawab, otonomi, dan kendali.

Menurut Hackman dan Oldham dalam Robbins (2006: 641-642): Ada lima dimensi karakteristik pekerjaan yaitu:

1. Skill Variety (Variasi ketrampilan). Variasi keterampilan yaitu derajat atau tingkatan di mana suatu tugas membutuhkan variasi keterampilan dan bakat dari karyawan sehingga tugas tersebut dapat diselesaikan dengan baik. Karyawan yang memiliki keahlian dan keterampilan yang tinggi akan mengalami kepuasan kerja bila dapat menyelesaikan pekerjaannya, yang sifatnya membutuhkan keterampilan dan keahlian untuk mengerjakannya. Dengan demikian pegawai dapat mengaktualisasikan dirinya, serta dapat mengembangkan bakat dan ketrampilannya.

2. Task identity ( Identitas/ Kejelasan Tugas). Identitas tugas yaitu derajat suatu tugas yang meminta penyelesaian secara menyeluruh yang dapat di identifikasi oleh seorang pekerja sehingga dapat diselesaikan dari awal hingga akhir dan memberikan hasil yang pasti.

3. Task Significance (Kekhususan Tugas). Kekhususan tugas yaitu derajat suatu tugas, dimana tugas tersebut mempunyai dampak terhadap kehidupan atau pekerjaan individu lain, baik di dalam organisasi maupun di luar organisasi.

4. Autonomy (Kewenangan dan Tanggungjawab). Merupakan tingkat kebebasan dan keleluasaan individu dalam menjalankan pekerjaan dan jadwalnya atau derajat suatu tugas yang memberikan kebebasan, wewenangan kepada pekerjaannya dalam menyusun dan menetapkan prosedur - prosedur yang akan digunakan untuk menyelesaikan tugas.

5. Feed back Umpan balik). Tingkat dimana karyawan mendapat umpan balik dari pengetahuan mngenai hasil dari pekerjaannya. Umpan balik mengacu pada informasi yang diberikan kepada seorang karyawan atas prestasi yang dicapainya dalam pekerjaan.

Komitmen Organisasional. Beberapa pengertian atau definisi komitmen organisasi. Konsep komitmen organisasi telah didefinisikan dan diukur dengan berbagai cara yang berbeda. Menurut Cherirington (1996) dalam Khikmah (2005) komitmen organisasi sebagai nilai personal, yang kadang-kadang mengacu sebagai sikap loyal pada perusahaan. 
Robbins (2003) mengemukakan komitmen organisasi merupakan salah satu sikap yang merefleksikan perasaan suka atau tidak suka terhadap organisasi tempat bekerja. Komitmen organisasi ialah sikap karyawan yang tertarik dengan tujuan, nilai dan sasaran organisasi yang ditunjukan dengan adanya penerimaan individu atas nilai dan tujuan organisasi serta memiliki keinginan untuk berafiliasi dengan organisasi dan kesediaan bekerja keras untuk organisasi sehingga membuat individu betah dan tetap ingin bertahan di organisasi tersebut demi tercapainya tujuan dan kelangsungan organisasi.

Komitmen organisasi adalah suatu kondisi yang dirasakan oleh pegawai yang dapat menimbulkan perilaku positif yang kuat terhadap organisasi kerja yang dimiliki, dalam bentuk continuance commitment, Affective commitment, normative commitment (Allen dan Meyer, 1993)

Hubungan antar Variabel dan Pengembangan Hipotesis. Penelitian ini memiliki empat komponen variabel yang saling berhubungan satu sama lain. Hubungan antar variabel dapat dijelaskan sebagai berikut:

H1: Karakteristik Pekerjaan berpengaruh positif terhadap Komitmen

Organisasional pada Dinas Kesehatan Kabupaten Pekalongan.

H2: Kompetensi berpengaruh positif terhadap Komitmen Organisasional pada Dinas Kesehatan Kabupaten Pekalongan.

H3: Karakteristik Pekerjaan berpengaruh positif terhadap Kinerja Pegawai pada Dinas Kesehatan Kabupaten Pekalongan.

H4 Kompetensi berpengaruh positif terhadap Kinerja Pegawai pada Dinas Kesehatan Kabupaten Pekalongan

H5: Komitmen Organisasional berpengaruh positif terhadap kinerja pegawai pada Dinas Kesehatan Kabupaten Pekalongan.

\section{METODE}

Metode Survei. Tujuan yang hendak dicapai dalam penelitian ini adalah untuk memperoleh informasi tentang pengaruh karakteristik pekerjaan dan kompetensi terhadap kinerja melalui komitmen organisasional di Kantor Dinas Kesehatan Kabupaten Pekalongan. Untuk memperoleh informasi tersebut diatas maka peneliti menggunakan pendekatan, kuantitatif dan kualitatif.

Pendekatan kuantitatif adalah penelitian yang bentuk datanya bersifat numerik, yaitu data yang berupa angka-angka atau gejala dan peristiwa yang diangkakan. Penelitian kuantitatif ini merupakan kegiatan penelitian yang berorientasi pada hasil yang berupa kesimpulan yang bersifat pasti dan jelas serta pada umumnya dengan pembuktian hipotesis. Penelitian kuantitatif ini bersifat memecah kenyataan menjadi bagian-bagian dan mencari hubungan antar variabel yang terbatas, yang bertujuan untuk mencapai generalisasi guna meminimalkan atau memprediksi (Purwanti, 2000).

Kaitannya dengan penelitian ini adalah mencari data yang berhubungan dengan pengaruh Karakteristik pekerjaan dan Kompetensi terhadap kinerja dengan mediasi Komitmen Organisasi di Dinas Kesehatan Kabupaten Pekalongan melalui penyebaran angket yang sudah diisi bobot nilai, kemudian hasilnya dianalisis untuk membuktikan hipotesis. Pendekatan kualitatif mencoba memperoleh gambaran yang lebih mendalam dan memahami makna dari suatu fenomena.

Pengumpulan data dilakukan melalui metode survey mengenai faktor-faktor yang 
merupakan pendukung terhadap Karakteristik pekerjaan dan Kompetensi terhadap kinerja dengan mediasi Komitmen Organisasi di Dinas Kesehatan Kabupaten Pekalongan.

Sampel. Populasi yang digunakan dalam penentuan sampel ini adalah Pegawai negeri Sipil pada Dinas Kesehatan Kabupaten Pekalongan. Teknik pengumpulan sampel menggunakan Metode Sensus yaitu meneliti seluruh elemen populasi yang ada dikurangi 1 pimpinan puncak dan 1 orang peneliti, sehingga jumlah sampel dalam penelitian ini sebanyak 104 responden.

Pengujian Instrumen. Penguji melalukan pengujian instrumen dengan uji validitas dan uji reliabilitas terhadap kuesioner yang digunakan dalam penelitian. Faktor analisis digunakan dalam pengujian validitas karena alat analisis ini merupakan salah satu metode statistik multivariat yang bertujuan untuk meringkas atau mengurangi data (variabel) yang akan diperlukan dalam analisis. Jika dari indikator variabel memiliki nilai $\mathrm{KMO}>0,5$ maka dikatakan telah sampel memenuhi/ kecukupan sampel dan jika memiliki nilai Loading Faktor lebih besar > 0,4 dapat dikatakan indikator tersebut valid Faktor analisis dapat dgunakan untuk menentukan pola hubungan yang mendasari sejumlah variabel dan menentukan apakah informasi dapat diringkas dalam sejumlah factor yang lebih kecil (Hair, et. al, 1995,h.365-391; SPSS. Inc, 1998, h. 3I7). Hasil uji validitas (Tabel 1) mengindikasikan semua indikator dari semuavariabel yang diteliti adalah valid.

Uji reliabilitas ini diukur dengan menggunakan koefisien alpha (Cronbach alpha) dari hasil perhitungan dengan menggunakan program statistik SPSS 16 for windows dengan $\alpha$ hitung diatas 0,7 instrumen penelitian tersebut reliabel apabila pengujian tersebut menunjukkan alpha hitung lebih dari 0,7 sehingga dapat disimpulkan bahwa instrumen yang digunakan dalam penelitian ini memiliki tingkat reliabilitas yang cukup memadai pula Sekaran (1992). Hasil uji reliabilitas (Tabel 2) menunjukkan hasil yang riliabel.

Tabel 1. Hasil Uji Validitas (Analisis Faktor)

\begin{tabular}{lrrrr}
\hline \multicolumn{1}{c}{ Variabel } & KMO & Indikator & $\begin{array}{c}\text { Loading } \\
\text { Factor }\end{array}$ & Keterangan \\
\hline Karakteristik & 0,815 & X1.1 & 0,459 & Valid \\
Pekerjaan & & X1.2 & 0,554 & Valid \\
& & X1.3 & 0,631 & Valid \\
& & X1.4 & 0,691 & Valid \\
& & X1.5 & 0,704 & Valid \\
& & X1.6 & 0,747 & Valid \\
& & X1.7 & 0,671 & Valid \\
& & X1.9 & 0,614 & Valid \\
& & X1.10 & 0,585 & Valid \\
& & X1.11 & 0,692 & Valid \\
& & X1.12 & 0,632 & Valid \\
& & X1.14 & 0,537 & Valid \\
Kompetensi & 0,833 & X2.1 & 0,472 & Valid \\
& & X2.2 & 0,798 & Valid \\
& & X2.3 & 0,569 & Valid \\
& & X2.4 & 0,717 & Valid \\
\hline
\end{tabular}




\begin{tabular}{|c|c|c|c|c|}
\hline \multirow{18}{*}{$\begin{array}{l}\text { Komitmen } \\
\text { Organisasional }\end{array}$} & \multirow{18}{*}{0,838} & $\mathrm{X} 2.5$ & 0,794 & Valid \\
\hline & & X2.6 & 0,687 & Valid \\
\hline & & X2.7 & 0,528 & Valid \\
\hline & & X2.8 & 0,482 & Valid \\
\hline & & X2.9 & 0,601 & Valid \\
\hline & & $\mathrm{X} 2.10$ & 0,569 & Valid \\
\hline & & X2.11 & 0,580 & Valid \\
\hline & & $\mathrm{X} 2.12$ & 0,687 & Valid \\
\hline & & $\mathrm{X} 2.13$ & 0,692 & Valid \\
\hline & & $\mathrm{X} 2.14$ & 0,744 & Valid \\
\hline & & $X 2.15$ & 0,698 & Valid \\
\hline & & $\mathrm{X} 2.16$ & 0,688 & Valid \\
\hline & & Y1.1 & 0,550 & Valid \\
\hline & & Y1.3 & 0,532 & Valid \\
\hline & & Y1.4 & 0,622 & Valid \\
\hline & & Y1.5 & 0,779 & Valid \\
\hline & & Y1.6 & 0,649 & Valid \\
\hline & & Y1.7 & 0,709 & Valid \\
\hline \multirow{24}{*}{ Kinerja } & \multirow{24}{*}{0,870} & Y1.8 & 0,607 & Valid \\
\hline & & Y1.9 & 0,653 & Valid \\
\hline & & Y1.10 & 0,733 & Valid \\
\hline & & Y1.11 & 0,805 & Valid \\
\hline & & Y1.12 & 0,438 & Valid \\
\hline & & Y1.13 & 0,669 & Valid \\
\hline & & Y1.14 & 0,483 & Valid \\
\hline & & Y1.15 & 0,549 & Valid \\
\hline & & Y1.16 & 0,502 & Valid \\
\hline & & Y1.17 & 0,581 & Valid \\
\hline & & Y1.18 & 0,750 & Valid \\
\hline & & Y1.19 & 0,668 & Valid \\
\hline & & Y2.1 & 0,761 & Valid \\
\hline & & Y2.2 & 0,787 & Valid \\
\hline & & Y2.3 & 0,732 & Valid \\
\hline & & Y2.4 & 0,767 & Valid \\
\hline & & Y2.5 & 0,667 & Valid \\
\hline & & Y2.6 & 0,768 & Valid \\
\hline & & Y2.7 & 0,510 & Valid \\
\hline & & Y2.8 & 0,666 & Valid \\
\hline & & Y2.9 & 0,702 & Valid \\
\hline & & Y2.11 & 0,663 & Valid \\
\hline & & Y2.12 & 0,596 & Valid \\
\hline & & $\mathrm{Y} 2.13$ & 0,625 & Valid \\
\hline
\end{tabular}

Tabel 2 . Hasil Uji Reliabilitas

\begin{tabular}{lccc}
\hline \multicolumn{1}{c}{ Variabel } & $\begin{array}{c}\text { Alpha } \\
\text { Crounbach }\end{array}$ & Rule of thumb & Keterangan \\
\hline Karakteristik Pekerjaan & 0,853 & 0,7 & Reliabel \\
Kompetensi & 0,910 & 0,7 & Reliabel \\
Komitmen organisasional & 0,906 & 0,7 & Reliabel \\
Kinerja & 0,887 & 0,7 & Reliabel \\
\hline
\end{tabular}




\section{Uji Statistik}

1. Uji Koefisien Determinasi. Uji koefisien determinasi pada intinya mengukur seberapa besar kemampuan model dalam menerangkan variabel dependen atau kemampuan menjelaskan model.

Model $1: \mathrm{Y} 1=\mathrm{a} 1+\mathrm{b} 1 \mathrm{X} 1+\mathrm{b} 2 \mathrm{X} 2+\mathrm{e} 1$

Model $2: \mathrm{Y} 2=\mathrm{a} 2+\mathrm{b} 3 \mathrm{X} 1+\mathrm{b} 4 \mathrm{X} 2+\mathrm{b} 5 \mathrm{Y} 1+\mathrm{e} 2$.

Dari Tabel 3, hasil uji regresi model pertama, menunjukkan nilai Adjusted R Square = 0,289, artinya Karakteristik Pekerjaan dan Kompetensi mampu menjelaskan Komitmen Organisasional sebesar 28,9\%. Sisanya sebesar $71,1 \%$ dipengaruhi oleh faktor lain diluar variable Karakteristik Pekerjaan dan Kompetensi yang tidak ikut dijadikan instrument penelitian.

Hasil uji regresi model kedua menunjukan nilai Adjusted R Square $=0,492$ artinya Karakteristik Pekerjaan, Kompetesi dan Komitmen Organisasional mampu menjelaskan Kinerja sebesar 49.2\%. Sisanya sebesar 50,8\% dipengaruhi oleh factor lain diluar variable Karakteristik Pekerjaan, Kompetesi dan Komitmen Organisasional yang tidak ikut dijadikan instrument penelitian.

Tabel 3. Hasil Uji Regresi

\begin{tabular}{|c|c|c|c|c|c|c|}
\hline \multirow[t]{2}{*}{ Model } & \multirow{2}{*}{$\begin{array}{l}\text { Adjusted R } \\
\text { Square } \\
\end{array}$} & \multicolumn{2}{|c|}{ Uji F } & \multicolumn{2}{|c|}{ Uji t } & \multirow[t]{2}{*}{ Ket. } \\
\hline & & $\mathrm{F}$ & Sig & $\beta$ & sig & \\
\hline Persamaan I & 0.289 & 19.456 & 0.000 & & & \\
\hline $\begin{array}{l}\text { 1. Karakteristik Pekerjaan } \\
\text { terhadap Komitmen } \\
\text { Organisasional. } \\
\text { 2. Kompetensi terhadap } \\
\text { Komitmen } \\
\text { Organisasional }\end{array}$ & & & & $\begin{array}{l}0.097 \\
0.475\end{array}$ & $\begin{array}{l}0.474 \\
0.001\end{array}$ & $\begin{array}{l}\text { Hipotesis } \\
\text { ditolak } \\
\text { Hipotesis } \\
\text { diterima }\end{array}$ \\
\hline Persamaan II & 0.492 & 30.427 & 0.000 & & & \\
\hline $\begin{array}{l}\text { 1. Karakteristik Pekerjaan } \\
\text { terhadap Kinerja. }\end{array}$ & & & & 0.250 & 0.031 & $\begin{array}{l}\text { Hipotesis } \\
\text { diterima }\end{array}$ \\
\hline $\begin{array}{l}\text { 2. Kompetensi terhadap } \\
\text { Kinerja }\end{array}$ & & & & 0.465 & 0.000 & $\begin{array}{l}\text { Hipotesis } \\
\text { diterima }\end{array}$ \\
\hline $\begin{array}{l}\text { 3. Komitmen } \\
\text { Organisasional terhadap } \\
\text { Kinerja }\end{array}$ & & & & 0.069 & 0.446 & $\begin{array}{l}\text { Hipotesis } \\
\text { ditolak }\end{array}$ \\
\hline
\end{tabular}

2. Pengujian hipotesis. Pengujian hipotesis menggunakan uji $t$ dilakukan untuk mengetahui ada tidaknya pengaruh variable bebas terhadap variable terikat secara parsial. Dikatakan signifikan apabila nilai Signifikasi t dibawah atau sama dengan 0,05. Dari Table 3 hasil uji model pertama, pengaruh variabel bebas terhadap variabel terikat dapat dijelaskan dari Hipotesis berikut:

H1: Karakteristik Pekerjaan brpengaruh positif terhadap Komitmen Organisasional.

Hasil pengujian hipotesis pertama menunjukkan nilai signifikansi sebesar 0.474 > 0.05 sehingga hipotesis ditolak.

H2: Kompetensi berpengaruh positif terhadap Komitmen Organisasional.

Hasil pengujian hipotesis kedua menunjukkan nilai signifikansi sebesar $0.001<$ 
0.05 sehingga hipotesis diterima dan berpengaruh positif, ditunjukkan dari nilai beta sebesar 0.475

Dari hasil uji model kedua, pengaruh variabel bebas terhadap variabel terikat dapat dijelaskan dari Hipotesis berikut:

H3: Karakteristik Pekerjaan berpengaruh positif terhadap Kinerja.

Hasil pengujian hipotesis ketiga menunjukkan nilai signifikansi sebesar $0.031<$ 0.05 sehingga hipotesis diterima dan berpengaruh positif, ditunjukkan dari nilai beta sebesar 0.250

H4: Kompetensi berpengaruh positif terhadap Kinerja.

Hasil pengujian hipotesis keempat menunjukkan nilai signifikansi sebesar 0.000 $<0.05$ sehingga hipotesis diterima, dan berpengaruh positif, ditunjukkan dari nilai beta sebesar 0.465

H5: Komitmen organisasional berpengaruh positif terhadap kinerja.

Hasil pengujian hipotesis kelima menunjukkan nilai signifikansi sebesar $0.446>$ 0.05 sehingga hipotesis ditolak.

3. Uji Mediasi. Dari hasil pengujian hipotesis karakteristik pekerjaan tidak berpengaruh terhadap komitmen organisasional dan Komitmen Organisasional tidak berpengaruh terhadap kinerja, namun Karakteristik pekerjaan dan kompetensi berpengaruh langsung terhadap kinerja, sehingga Komitmen Organisasional tidak memediasi hubungan antara karakteristik pekerjaan dan kompetensi terhadap kinerja.

\section{HASIL DAN PEMBAHASAN}

Dari analisa regresi diperoleh hasil bahwa: Pertama. Karakteristik pekerjaan tidak berpengaruh terhadap komitmen organisasional, sehingga tidak memberi dukungan terhadap hipotesis yang diajukan maupun hasil penelitian Yunita Tamalero,Bambang S, dan Djamhur Hamid, (2011); Djastuti (2011); Mulyani dan Soliha (2014); Rusminingsih dan soliha (2014) yang menyimpulkan bahwa karakteristik pekerjaan mempunyai pengaruh yang positif dan signifikan terhadap komitmen organisasional. Hal ini menggambarkan bahwa pemahaman responden terhadap persepsi tentang komitmen organisasional masih kurang. Karakteristik pekerjaan yang menjadi tanggungjawab dari berbagai tugas, belum mampu membuat karyawan merasakan kepuasan sehingga menimbulkan prilaku positif yang kuat terhadap organisasi kerja yang dimilikinya dalam bentuk komitmen yang kuat. Kedua. Kompetensi berpengaruh positif dan signifikan terhadap komitmen organisasional. Hal ini sesuai dengan hipotesis yang diajukan dan sejalan dengan penelitian Sudarmanto (2009); Kartawijaya (2012); Rusminingsih dan Soliha (20140 yang menyimpulkan kompetensi berpengaruh positif dan signifikan terhadap Komitmen Organisasi .Hal ini juga selaras dengan Spencer and Spencer (1993:9) mengemukakan bahwa kompetensi individu merupakan karakter sikap dan perilaku, atau kemampuan individual yang relatif bersifat stabil ketika menghadapi suatu situasi di tempat kerja yang terbentuk dari sinergi antara watak, konsep diri, motivasi internal, serta kapasitas pengetahuan kontekstual. Sehingga dapat disimpulkan bahwa kompetensi yang dimilki pegawai sesuai dengan tanggungjawab tugas pokok dan fungsinya dapat menimbulkan prilaku positif terhadap organisasi kerja yang dimilikinya. Ketiga. Karakteristik pekerjaan berpengaruh positif dan signifikan terhadap kinerja. Hal ini sesuai dengan hipotesis yang diajukan dan sejalan dengan penelitian Laily (2009); Pardjono (2011); Mulyani dan Soliha (2014); Rusminingsih dan Soliha (2014) yang menyimpulkan 
bahwa ada pengaruh positif yang signifikan antara karakteristik pekerjaan terhadap kinerja pegawai. Hal ini sejalan dengan pendapat Gibson (1997) mendefinisikan kinerja sebagai hasil dari pekerjaan yang terkait dengan tujuan organisasi seperti kualitas, kuantitas dan effisiensi kerja. Tiap-tiap pekerjaan memiliki tuntutan yang berbeda terhadap individu yang mengerjaannya. Kemampuan intelektual atau fisik khusus yang diperlukan untuk menyelesaikan pekerjaan tergantung pada persyaratan-persyaratan kemampuan yang dibutuhkan oleh pekerjaan tersebut. Kondisi tersebut berlaku di Dinas Kesehatan Kabupaten Pekalongan. Keempat. Kompetensi berpengaruh positif dan signifikan.terhadap kinerja. Hal ini sesuai dengan hipotesis yang diajukan dan sejalan dengan penelitian Suheryati (2013); Rusminingsih dan Soliha (2014) yang menyatakan bahwa kompetensi berpengaruh positif dan signifikan terhadap kinerja pegawai. Hal ini sejalan dengan pendapat Spencer and Spencer (1993:9) mengemukakan bahwa kompetensi individu merupakan karakter sikap dan perilaku, atau kemampuan individual yang relatif bersifat stabil ketika menghadapi suatu situasi di tempat kerja yang terbentuk dari sinergi antara watak, konsep diri, motivasi internal, serta kapasitas pengetahuan kontekstual, sehingga semakin tinggi kemampuan dan kompetensinya maka kinerjanya akan meningkat. Kelima. Komitmen organisasional tidak berpengaruh terhadap kinerja. Hal ini tidak sesuai dengan hipotesis yang diajukan dan tidak sejalan dengan penelitian yang dilakukan oleh Mulyanto dan Sutapa (2009); Baihaqi (2010); Mulyani dan Soliha (2014); Rusminingsih dan Soliha (2014) yang menyimpulkan komitmen organisasi berpengaruh positif dan signifikan terhadap kinerja karyawan.

Hal ini tidak sejalan dengan pendapat (Allen dan Meyer, 1993).yang menyatakan komitmen organisasi adalah suatu kondisi yang dirasakan oleh pegawai yang dapat menimbulkan perilaku positif yang kuat terhadap organisasi kerja yang dimiliki, dalam bentuk continuance commitment, Affective commitment, normative commitment. Di Dinas Kesehatan Kabupaten Pekalongan, komitmen organisasional belum menjadi tanggungjawab moral maupun keinginan bagi sebagian pegawai Dinas Kesehatan. Kemampuan dalam menyelesaikan tugas dan tanggungjawabnya belum menjadi kebanggaan sebagai bagian dari organisasi kerjanya. Sebagian masih menilai kompetensi dan tanggungjawabnya hanya dapat dinilai dari reward atau kompensasi yang diterimanya, bukan sebagai pengorbanan untuk kemajuan organisasinya.

\section{Implikasi Manajerial}

1. Hasil Penelitian menunjukkan bahwa karakteriktik pekerjaan dan kompetensi Pegawai Dinas Kesehatan Kabupaten Pekalongan dapat meningkatkan kinerja, Namun komitmen afektif, komitmen kontinuan dan komitmen normatif pada diri pegawai Pegawai Dinas Kesehatan Kabupaten Pekalongan berpengaruh tidak signifikan pada keinginan mereka untuk berpindah dari organisasi.

Penelitian ini juga menemukan bahwa Kompetensi dari pegawai meningkatkan komitmen organisional. Kompetensi dari pegawai membentuk sikap individu yang mendorong komitmen afektif pegawai Dinas Kesehatan Kabupaten Pekalongan Peningkatan komitmen afektif akan mengurangi keinginan berpindah dan keengganan pekerja untuk menyampaikan idenya. Pekerja juga akan memiliki motivasi untuk memberikan kontribusi yang berarti bagi organisasi (Meyer et al., 2001). Hal yang perlu menjadi catatan adalah pegawai yang memiliki kontinuan tinggi akan memilih tetap bergabung pada organisasi dikarenakan pertimbangan kerugian yang akan mereka peroleh jika keluar sehingga pegawai rentan 
keluar dari organisasi jika mereka mendapatkan alternatif pekerjaan yang lebih baik. Semakin tinggi tingkat kompetensi pegawai juga akan berdampak pada meningkatnya komitmen normatif. Konsekuensi dari tingginya komitmen normatif adalah perilaku produktif meliputi kehadiran pekerja, kinerja dan citizenship. Pekerja dengan komitmen normatif yang tinggi akan merasa memiliki kewajiban dan tugas. Hal tersebut akan mempengaruhi kehadiran dan kinerja dalam bekerja (Meyer et al., 2001). Sedangkan pada keinginan berpindah, penelitian ini menemukan bahwa pengaruh kompetensi tidak signifikan.

Temuan dalam penelitian ini dapat memberikan arahan kepada pemegang kebijakan di Dinas Kesehatan sebagai dasar penentuan kebijakan yang tepat untuk mempertahankan dan meningkatkan kinerja, komitmen afektif, komitmen kontinuan dan komitmen normatif pegawai, juga, untuk mengurangi keinginan berpindah mereka. Sehingga, temuan ini dapat menjadi inspirasi bagi pemegang kebijakan di organisasi - organisasi publik untuk meningkatkan kinerja dari pegawai pada organisasi tersebut.

2. Agar kinerja pegawai Dinas Kesehatan Kabupaten Pekalongan dapat optimal maka pegawai Dinas Kesehatan Kabupaten Pekalongan perlu memiliki kompetensi yang memadai dalam bidang tugasnya. Terpenuhinya kesesuaian antara karakteristik pekerjaan dan kompetensi serta tingkat kemampuan dengan kebutuhan tugas merupakan syarat terbentuknya aparatur yang profesional sehingga diharapkan akan menumbuhkan prilaku positif yang kuat terhadap organisasi kerja dalam bentuk komitmen organisasional yang tinggi.

\section{PENUTUP}

Simpulan. Penelitian ini menunjukkan bahwa: Pertama. Karakretistik pekerjaan tidak berpengaruh terhadap komitmen organisasional Hal ini mengindikasikan bahwa sebagian pegawai Dinas Kesehatan Kabupaten Pekalongan dalam melaksanakan tugasnya sebatas bertangungjawab terhadap tugas pekerjaannya dan hanya merasa puas jika mampu menyelesaikan tugas sesuai dengan karakteristik pekerjaannya.Komitmen organisasional belum menjadi tanggungjawab moral maupun keinginan bagi sebagaian pegawai Dinas Kesehatan. Kedua. Kompetensi mempunyai pengaruh yang positif dan signifikan terhadap Komitmen Orgaisasional. Semakin tinggi pegetahuan seseorang dalam melaksanakan tugas sesuai dengan pekerjaannya yang dilandasi kemampuan dalam kompetensi secara intelektual, emosional, dan Sosial untuk mencapai standar yang diharapkan mampu meningkatkan kinerja dan mampu menumbuhkan komitmen organisasional pegawai Dinas Kesehatan Kabupaten Pekalongan. Hal ini mengindikaskan bahwa pegawai Dinas Kesehatan Kabupaten Pekalongan mampu tampil secara kompeten menghadapi kesulitan dalam melaksanakan tugas yang diberikan oleh pimpinan. Pegawai Dinas Kesehatan Kabupaten Pekalongan juga menyadarai bahwasannya kompetensi yang dimiliki mendukung mereka untuk menyelesaikan pekerjaan dan meningkatkan kinerjanya. Ketiga. Karakteristik pekerjaan berpengaruh positif dan signifikan terhadap kinerja. Tiap-tiap pekerjaan memiliki tuntutan yang berbeda terhadap individu yang mengerjaannya.Kemampuan intelektual atau fisik khusus yang diperlukan untuk menyelesaikan pekerjaan tergantung pada persyaratan - persyaratan kemampuan yang dibutuhkan oleh pekerjaan tersebut. Kondisi tersebut berlaku di Dinas Kesehatan Kabupaten Pekalongan. Keempat. Kompetensi berpengaruh positif dan signifikan.terhadap kinerja, maka dapat disimpulkan bahwa semakin tinggi kemampuan 
dan kompetensi seorang pegawai maka kinerjanya akan meningkat. Kelima. Komitmen organisasional tidak berpengaruh terhadap kinerja. komitmen organisasi adalah suatu kondisi yang dirasakan oleh pegawai yang dapat menimbulkan perilaku positif yang kuat terhadap organisasi kerja yang dimiliki, dalam bentuk continuance commitment, Affective commitment, normative commitment. Di Dinas Kesehatan Kabupaten Pekalongan, komitmen organisasional belum menjadi tanggungjawab moral maupun keinginan bagi sebagian pegawai Dinas Kesehatan. Kemampuan dan kompetensi yang dimiliki mampu meningkatkan kinerja karena nilai kompensasi yang diterima, bukan sebagai pengorbanan sebagai indikator komitmen organisasional yang tinggi

Saran. Saran yang dapat disampaikan oleh peneliti berdasarkan kesimpulan diatas adalah sebagai berikut: Pertama. Karakteristik pekerjaan, kompetensi dan komitmen organisasional pegawai di Dinas Kesehatan Kabupaten Pekalongan yang sudah cukup baik agar lebih ditingkatkan lagi terutama untuk karaktersitik pekerjaan dan kompetensi yang mempunyai pengaruh yang positif dan signifikan terhadap kinerja pegawai. Memberikan arahan kepada pemegang kebijakan di Dinas Kesehatan sebagai dasar penentuan kebijakan yang tepat untuk mempertahankan dan meningkatkan kinerja, komitmen afektif, komitmen kontinuan dan komitmen normatif pegawai, juga untuk mengurangi keinginan berpindah mereka. Sehingga menjadi inspirasi bagi pemegang kebijakan di organisasi-organisasi publik untuk meningkatkan kinerja dari pegawai pada organisasi tersebut. Manajemen Dinas Kesehatan harus mampu merubah kondisi tersebut sehingga pegawai yang semula tidak termotivasi untuk tetap melanjutkan bekerja pada organisasi ini sebagai sikap bahwa tetap bekerja di organisasi ini merupakan kewajiban moral. Kedua. Untuk meningkatkan kinerja pegawai, manajemen Dinas Kesehatan Kabupaten Pekalongan sebaiknya mengikutsertakan para pegawai dalam kegiatan diklat tehnis fungsional berjenjang dalam rangka meningkatkan ketrampilan dan kompetensinya.

\section{DAFTAR RUJUKAN}

Allen, Natalie J and Meyer, John P, (1990) "The Measurement And Antecedents OfAffective, Countinuance And Normative Commitment To Organization,"Journal of Occupational Psychology," 63, 1-18.

Bass, Bernard $\mathrm{M}$ and Avolio, Bruce J, (1993)" Tansformational Leadership AndOrganizational Culture," Public Administration Quarterly," 17 (1), 112-121.

Benkhoff, Birgit, (1997) "Ignoring Commitment is Costly: New Approaches EstablishThe Missing Link Between Commitment and Performance," Journal of Human Resources," 50 (6)

Bhuian, S.N. and Menguc, B. (2002) "An Extension and Evaluation of Job Characteristics, Organizational Commitment, and Job Satisfaction in An Expatriate, GuestWorker, Sales Setting, "The Journal of Personal Selling \& Sales Management," 22 (1), 1-11

Chen, Li Yueh, (2004) "Examining The Effect Of Organization Culture And Leadership Behaviors On Organizational Commitment, Job Satisfaction,Adan Job Performance At Small And Middle-Sized Firma Of Taiwan," Journal of American Academy of Business," 5 (1/2) September, 432-438.

Cokroaminoto, (2007) "Membangun Kinerja (Memaknai Kinerja Karyawan), "Google/15012008/cokroaminoto.wordpress.com/20070523/memaknai kinerja-karyawan." 
Cooper, R. Donald \& C. William Emory, (2006) "Metode Penelitian Bisnis", Penerbit Erlangga, Jilid 1, Edisi Kelima.

Dessler, G. (1997) Human Resources Management. 7th Edition, Prentice-Hall, Inc.

Djastuti, Indi, (2011) "Pengaruh Karakteristik Pekerjaan terhadap Komitmen Organisasi Karyawan Tingkat Manajerial Perusahaan di Jawa Tengah," Jurnal Penelitian Manajemen Sumber Daya Manusia.

Gibson, James L et., al (2006) "Organizations (Behavior, Structure, Processes)," Twelfth Edition, McGrow Hill.

Gibson, Ivancevich, \& Donnelly. (1997) “Organizations:Behavior," Structure, Processes, Irwin

Glisson, C., and Durick, M. (1988) "Predictors of Job Satisfaction and Organizational Commitment in Human Service Organizations," Admisnistrative Science Quarterly, $33,61-81$

Hair, J. F, Black, W. C, Babin, B.J, Anderson, R. E., \& Tatham, R. L., (2006)“ M ultivariate data Analysis", Sixth Edition, New Jersey: Prentice Hall.

Indrastuti, (2008) "Analisis Pengaruh Karakteristik Pekerjaan dan Iklim Organisasi Terhadap Kinerja Dengan Mediasi Komitmen Organisasional (Studi Pada Pegawai Negeri Sipil Dinas Pertanian Dan Peternakan Kabupaten Pati)," Tesis, tidak dipublikasikan.

Isywara Mahendratto, Mental Blocks Specialist, Servoclinic.com/2007/08/ 09 /kinerja-karyawan-menurun.

Laily, Nur, (2009) "Pengaruh Karakteristik Pekerjaan terhadap Kepuasan Kerja dan Kinerja Manajerial Industri Pupuk di Indonesia,' Jurnal Penelitian Manajemen Sumber Daya Manusia.

Luthans, Fred, (2006) "Perilaku Organisasi”, Edisi Sepuluh, Penerbit Andi, Yogyakarta

Luthan, F., (2006) "Organizational Bahavior Organizational Bahavior," 10th Edition,

Mahmudi, (2005) "Manajemen Kinerja Sektor Publik", Akademi Manajemen Perusahaan YKPN.

Mathis, Robert L dan Jackson, John H, (2001) “Manajemen Sumberdaya Manusia,”Buku 1, Salemba Empat Jakarta.

McKinnon, Jill L et al, (2003) " Organizational Culture: Associatin with commitment, Job Satisfaction, Propensity to Remain, and Information sharing in Taiwan," International Journal Of Business Studies, 11 (1) June, 25 -44.

McNeese-Smith, Donna, (1996) "Increasing Employee Productivity, Job Satisfaction, and Organizational Commitment," Hospital and Health Services Ad, 41 (2), 160-175

Mitrani, A, Daziel, M. and Fitt, D., (1992) "Competency Based Human Resource Mangement:Valua-Driven Strategies for Recruitmen, Development and Reward," Kogan Page Limited: London

Moon, M. Jae, (2000) "Organizational Commitment Revisited In New PublicManagement (Motivation, Organizational, Culture, Sector, and ManajerialLevel," Public Performance \& Management Review, 24 (2) Desember, 177-194.

Mowday, R.T., Porter, L.W. and Steers, R.M. (1982) Employee-Organization Linkages. San Diego. CA: Academic Press.

Mulyani, Sri dan Euis Soliha, (2014) "Pengaruh Karakteristik Pekerjaan dan Motivasi terhadap Komitmen Organisasional, serta dampaknya terhadap Kinerja Guru," Performance Jurnal Personalia, Financial, Operational, Marketing \& Sistem 
Informasi, 20 (2).

Mulyanto dan Sutapa Hardaya, (2009) "Pengaruh Motivasi, Kepuasan Kerja, dan Komitmen Organisasi terhadap Kinerja Pegawai pada Dinas Tenaga Kerja dan Transmigrasi Propinsi Daerah Istimewa Yogyakarta," Jurnal Penelitian Manajemen Sumber Daya Manusia.

Nasrudin, M.A., (2008) "Pengaruh Kemampuan Kerja dan Motivasi terhadap Kinerja Pegawai dengan mediasi Komitmen Organisasional (Studi pada Sekretariat Daerah Kabupaten Batang), Tesis, tidak dipublikasikan.

Porter, L.W., Steers, R.M., Mowday, R.T. and Boulian. (1983) "Organizational Commitment, Job Satisfaction, and Turnover among Psychiatric Tecnicians," Journal of Applied Psychology, 59(5), 603-609

Prawirosentono, Suyadi, (2000) "Kebijakan Kinerja Karyawan," BPFE,Yogyakarta.

Robbins, Stephen P, (2006) “Perilaku Organisasi,” Edisi kesepuluh, PT IndeksJakarta.

Rusminingsih dan Euis Soliha, (2014) "Pengaruh Kompetensi Guru dan Karakteristik Pekerjaan terhadap Kinerja dengan Mediasi Komitmen Organisasional (Studi pada Pendidik Pendidikan Anak Usia Dini di Kecamatan Pati," Jurnal Bisnis dan Manajemen, 2 (1).

Schein, Edgar H, (2004) "Organizational Culture and Leadership," Third Edition,Jossey -Bass Publishers, San Francisco.

Sing-Lee, M., and Chao Chang, S. (2006) Relationships Among Personality, Traits,

Spencer, M. Lyle and Spencer, M. Signe, (1993) "Competence at Work Modelas for SuperriorPerformance," John Wily \& Son, Inc, New York, USA.

Steers, R.M. (1977) "Antecedents and Outcomes of Organizational Commitment". Administrative Science Quarterly. 22, 46-56

Supriatna, Tjahya. (1993) "Sistem Administrasi Pemerintahan di Daerah," Jakarta: Bumi Aksara.

Undang - undang Nomor 32 Tahun 2014 tentang Pemerintahan Daerah ,Pasal 12

Undang - undang nomor 25 Tahun 2009 tentang Pelayanan Publik, Pasal 1

Van den Berg, Peter T and Jan A. Feij, (2003) "Complex Relationships Among Personality Traits, Job Characteristics, and Work Behaviors," International Journal of Selection and Assessment, 11 (4), December.

Windartini, (2006) Pengaruh Motivasi Kerja, Disiplin Kerja dan Karakteristik Pekerjaan Terhadap Kinerja Pegawai Pada Dinas Pertanian Kabupaten Temanggung, Tesis, tidak dipublikasikan 